\title{
Edebiyatta Sembol Dili ve Orhan Kemal’in “İki Buçuk” Adlı Hikâyesinde Sembol Dilinin Kullanımı
}

\author{
Gaye Belkız YETER'
}

\begin{abstract}
$\ddot{\mathbf{O} z}$
Bu çalışmada edebî metinlere etkili, özgün bir form kazandıran sembol dilinin kullanım şekillerine ve Orhan Kemal'in “İki Buçuk” adlı hikâyesindeki sembol diline yer verilecektir. Genellikle kahramanın psikolojik durumu ve ruhi büyüme sürecine göre şekillenen edebî eserlerin bilinmeyen, görünmeyen kısımlarını hem gözler önüne sermek hem de tahlil etmek için çeşitli inceleme yöntemleri mevcuttur. Bunlardan biri olan sembol dilinin tespiti okura ve araştırmacıya çeşitli bakışaçları sunar. Çünkü sanatkârların büyük bir kısmı düşüncelerini sembol, simge, imge ve birtakım göstergelerle aktarmaktadırlar. Türk edebiyatının önemli yazarlarından biri olan edebiyatın roman, öykü, tiyatro ve şïr türlerinde birçok eser ortaya koyan Orhan Kemal de kendisini ve düşüncelerini net ifadelerle anlatmak yerine sembol, simge ve imge gibi unsurlar yoluyla yansıtmayı tercih etmiştir. Makalemizde Orhan Kemal'in 1969'da Sait Faik Hikâye Armağanıyla ödüllendirilen "Önce Ekmek” adlı eserindeki "İki Buçuk" adlı hikâyesi sembol dili çerçevesinde incelenecektir. Orhan Kemal’in "İki Buçuk" adlı hikâyesindeki sembolik yapının işlevini ise metnin anlaşılmasında psikolojik bir çözümleme yöntemi olarak kabul etmek mümkündür. Çalışmamıza sembol dili ve özellikle de insanın duygu, düşünce ve davranış kalıplarını şekillendiren psikolojik çözümleme yöntemlerinden biri olan arketipsel sembolizm yön verecektir. Çünkü çoğunlukla metinde anlatılmak istenenler bazı sembollerle ortaya konur. Genellikle öykünün temelinde sembol, kavram ve imgeler kahramanlar vasitasıyla okura aktarılır. Orhan Kemal'in bu hikâyesinden hareketle yazar kahramanın ve kendisinin bilinç altındaki anlam derinliklerindeki saklı anlam şifrelerini, hikâye dilinde sembolik anlatımla yansıtmıştır. Kahramanın simgesel bir yolculuğa çıkması, onun kendini gerçekleştirmesini ve değerler dünyasını şekillendirmesini sağlar. Böylelikle sembollerin tespiti ve anlamlandırılması aracılı̆̆ıyla bilinç altındaki saklı kör noktalara ışık tutabiliriz.
\end{abstract}

Anahtar kelimeler: Sembol dili, arketipsel sembolizm, Orhan Kemal, İki Buçuk.

\section{Symbol Language in Literature and The Usage of Symbol Language in Orhan Kemal's “İki Buçuk" Story}

\begin{abstract}
This study includes usage patterns of symbol language which brings to literary texts an effective and original form and symbol language in Orhan Kemal's "Iki Bucuk" story. Various examination methods are present both to reveal and analyze of unknown and invisible parts of literary works which generally take form according to the psychological state and psychical growth process of protagonist. Symbol language is one of them and determination of it gives various points of view to especially reader and researcher. Since, a great part of the artists convey their ideas through image and some signs. Orhan Kemal one of the important writers of Turkish Literature has produced works in the kinds of literature like novel, story, theater and poem. It is possible to state that Orhan Kemal also reflects on himself and his thoughts via elements such as sign and image instead of clear
\end{abstract}

Dr. Öğr. Üyesi, Erzincan Binali Yıldırım Üniversitesi, Fen Edebiyat Fakültesi, Türk Dili ve Edebiyatı Bölümü, gayeyeter@hotmail.com [Makale kayıt tarihi: 9.7.2018-kabul tarihi: 15.8.2018] 
expressions. "Iki Bucuk" story in the work of Orhan Kemal named "Önce Ekmek" which is rewarded Sait Faik Story Gift in 1969 is examined through symbol language that we has based our study on. It is possible to regard function of symbolic structure in the writer's story named "Iki Bucuk" as a psychological analysis method in understanding of the text. Our study is shaped by symbol language and especially archetypical symbolism which is one of the psychological analysis methods and gives form to patterns of thought, emotion and behavior of human. Since generally what is meant to be described in the text is revealed by some symbols. Symbol, concept and images are transferred to the reader by means of characters on the basis of the story. Orhan Kemal has reflected depth of meaning and hidden meaning passwords in the subconscious of protagonist and himself on story language via symbolic expression with reference to this story. Protagonist's setting out on a symbolic journey provides him to realize himself and shape his world of values. We could sort out subconscious hidden blind spots through the detection and interpretation of symbols.

Key words: Symbol language, archetypical symbolism, Orhan Kemal, İki Buçuk.

\section{Giriş}

"Sembol dili, edebî eseri her okunuşta yeniden üretilen dinamik ve canlı bir kaynağa dönüştürür" (Yllmaz, 2011: 54).

Edebiyat araştırmalarında 'sembol dili'nin kullanımı yenidir. Fakat 'sembol' kullanımını mit, destan, efsane gibi ilk anlatılara kadar götürmek mümkündür. "Sembol kullanma ihtiyacı, insanlık tarihinin ilk dönemlerinden itibaren, özellikle günümüze ulaşan, mitolojik öykü, destan, efsane ve kutsal metinlerde de kendisini hissettirir" (Yılmaz, 2011: 45-46). İlk dönemlerde sembol kullanımının bilinçli mi yoksa bilinçsiz mi yapıldığı hususunda üreticilerin niyet boyutunu bilmediğimiz için net kanılar söylememiz zordur. Geçmişten günümüze edebiyatın hemen her ürününde oldukça sembolik bir dil kullanıldı̆̆ı ve bazı sembolik değerlerin anlamlarının onunla ifade edilmeye çalışıldığı da yadsınamaz bir gerçektir.

"Sembolik dil veya anlatım, hemen hemen bütün dinlerde ve edebiyatlarda var olan ve başvurulan bir anlatım yöntemidir. Bu tür bir söylem her ne kadar yer yer yanlış/eksik anlamalara yol açsa da, yine de duygu ve düşüncelerin doğrudan değil de örtük bir biçimde, daha doğrusu birtakım sembolik değerler üzerinden dile getirilmesi anlatılanların daha ilgi çekici olmasına ve okuyucunun yaratıc düşünmesine vesile olmaktadır” (Demirel, 2012: 915).

Bir metni yorumlama sürecinde metinde okura çeşitli imkânlar sunan sembol gibi kolektif bilinçte yer alan kodlamalar bulunmaktadır. Bu kodlamalar sembol dilinde de ortaktır.
"Arketipler bilinç dıșıdır ve bu nedenle yalnızca varsayım olarak kabul edilebilir. Ancak biz onları ruhun içinde tekrar ortaya çıkan belirli tipik imgeler yoluyla fark ederiz. Çünkü arketiplerin kendi insiyatifleri ve enerjileri bulunmaktadır. Bu güçler onların (kendi sembolik stillerinde) anlamlı bir yorumlama yapmalarını kendi uyaranlarıyla herhangi bir duruma karışabilmelerini sağlamaktadır" (Karagözlü, 2012: 1406).

Arketipler her neslin ürettiği ortak sembollerdir. Toplumsal normların da bir şekilde bu gibi kodlanmış sembollerle oluşturulmasının iyi ve kötü yönlerinin olduğunu ifade etmek mümkündür. Örneğin Dede Korkut Hikâyeleri’ndeki "Kimin ki oğlu kızı yok, kara otağa kondurun, kara keçe altına döşeyin, kara koyun yahnisinden önüne getirin, yerse yesin, yemezse kalksın gitsin demişti. Oğlu olanı ak otağa, kızı olanı kızıl otağa kondurun, oğlu kızı olmayana Allah beddua etmiştir, biz de beddua ederiz, belli bilsin demiş idi” şeklindeki kodlanmış olan bu gibi semboller zamanla sosyal bir davranış modeline dönüşmektedir (Ergin, 1995: 21). Dede Korkut Hikâyeleri’nde Banı Çiçek’in otağının kırmızı olması motifi de buna benzer bir sembolik açılımları olan kodlama şeklidir (Özünel, 2015: 40). Halkın kırmızı 
otağı görünce destursuz bir şekilde otağa yaklaşamaması kolektif bilince yansıyan özel sembol unsurlarından biridir. Sembol diliyle yapılan bu sosyal davranış modelinde genellikle kara otağın kara leke gibi algılanması da toplumsal normlar içinde oldukça işlevseldir. Bu gibi toplumsal normlar içindeki kodlamalardan eski dönemlerde semboller aracılığıyla hayatın seyrine yön verildiği kanısına varmak mümkündür. Totemler de zamanla sembol diline dönüşmektedir. Meselâ hayvan, bitki gibi kavramların sembol dili içindeki işlevi oldukça fazladır. Kuşu buna örnek gösterebiliriz. Yirmi dört Oğuz boyunun damgasında kuş motifinin olması ve her birinin farklılıklarını bu sembolle ortaya koymaları sembollerin eski dönemlerden beri hayatın içinde ne kadar işlevsel olduğunu bize göstermektedir. Özellikle de akılda kalıcı olmaları sebebiyle sembollerin toplumun genelinde aynı anlamda karşılanmaları da önemlidir.

Yaşamlara, kültürlere göre farklıllk gösteren semboller ve sembolik dil hemen bütün edebî türlerde var olan ve metin içinde başvurulan bir anlatım yöntemidir. Özellikle de duyguların, düşüncelerin doğrudan değil de kapalı bir biçimde, daha doğrusu birtakım sembolik değerler üzerinden ifade edilmesi anlatılanların daha ilgi çekici olmasına ve okuyucunun yaratıcı düşünmesine yardımcı olmaktadır (Çobanoğlu, 2013: 58). Öyleyse edebî metinlerde sembolik dile sıkça başvurulduğunu söylemek mümkündür. Ancak şunu da belirtmekte fayda var ki çoğu çalışmada sembol ve imge terimleri birbirine yakın anlamlarda kullanılmaktadır. Amacımız doğrudan bu terimleri tanımlamak ve aralarındaki farkları belirlemek değildir. Lâkin bu çalışmayı daha iyi anlayabilmek için sembol ve imge terimlerinden kısaca bahsetmek araştırmacılara katkı sunacaktır.

Sembol, Grekçe 'sumbolos'tan Latinceye sumbolus şeklinde, oradan da Avrupa dillerine geçmiş ve işaret, iz, ima gibi anlamlara gelmektedir. G. Durand, sembolü her şeyden önce işaret kategorisine dâhil eder ve öyle tanımlar (Demirel, 2012: 917). Genellikle duyularla ifade edilemeyen bir şeyi belirten somut nesne, işaret, remiz, timsal, simge (TDK Türkçe Sözlük, 1986: 1278); herkes tarafından kabul edilmiş itibarî bir mekânın maddede sabitleşmiş şekli (Bilgegil, 1980: 14) gibi tanımlamaları bulunan sembolde “göstergenin anlamı başka bir göstergeye yükletilerek verilir" (Durmuş, 2011: 747).

Imge, Yunanca, meta: öte, aşırı ve pherein: taşımak, yüklenmek kelimelerinin birleşmesi ile oluşmuş bir kavram olan imge (metaphor, metafor metafora), "öteye taşımak" anlamına gelir. "Öte"ye taşınan, anlam olduğu gibi, metnin okuyanı/dinleyenidir de. "Öte"nin ne olduğu ise, gerçekliğin yeniden üretilmesi şeklinde tanımlanabilir (Durmuş, 2011: 746).

Anlamlandırılabilir soyut kavramlar da sembol dilinin kullanımına bir örnektir. Yani semboller aracılığıyla somut bir şeyden yola çıkılıp soyut bir teze ulaşılabilir. Böylelikle bir kavramı ya da unsuru olduğundan daha farklı nitelendirmek ve yeni çağrışımlara zemin hazırlamak mümkündür. Öte yandan semboller hem hayatın içinde hem de edebî metinde pek çok işleve sahiptir. Özellikle de dinî ve edebî metinlerde sıkça karşımıza çıkan sembol dili yazarların düşüncelerini ve duygularını daha estetik, yoğun bir şekilde ortaya koymalarına yardımcı olur.

\begin{abstract}
"Basit ve karmaşık şekillerden oluşan semboller, sayı, harf, canlı bir varlık veya eşya olabilir. Bu sembollerin hepsi belli bir düşünce gücü taşır. Taşıdıkları anlamlar tesadüfi değildir, kişiler tarafından özel olarak yüklenmiş anlamlardır. Semboller, hiç düşünülmemiş bakış açılarını, insanların anlayışına sunmayı sağlar. Dil, sembollerden meydana gelen bir dizgedir. Her sembolün belli bir anlamı vardır. Bu anlam, sembolü kullanan kişi veya kişiler tarafından belirlenir. Kişi bir isteği veya bilgiyi üstü kapalı olarak sunmak istiyorsa sembol kullanır. Yani semboller çeşitli sebeplerden ötürü açıça ifade edilemeyen veya edilmek istenmeyen düşünce ve isteklerin dışavurumudur. Toplumların hayat tarzları, düşünce dünyaları, inanç şekilleri farklı sembollerin ortaya çıkmasında etkili olmuştur. Dilek ve düşüncelerin dolaysız, net bir şekilde ifade edilmesinin
\end{abstract}


tehlikeli olacağı, mümkün olmayacağı veya hoş karşlanmayacağı durumlarda iş, sembollere düşer" (Ylldırım, 2009: 2385-2386).

Görüldüğü üzere edebî metinlerde sembollerin pek çok işlevi bulunmaktadır. Edebiyatın roman, öykü, tiyatro ve şiir türlerinde ürünler veren ve Türk hikâyeciliğinde önemli bir yere sahip olan Orhan Kemal'in de eserlerinde sembolizme başvurduğunu söylemek mümkündür. Özellikle de emekçi insanların sıkıntılarını dile getirmek istediği metinlerde düşüncelerini aktarabilmek için sembol dilinin anlam unsurlarına daha çok yer vermiştir. "Orhan Kemal'de hiçbir zaman ders vermek, akıl vermek, yukarıdan bakmak değildir. Gözlemlemek, aktarmak, özellikle de olayların doğal gelişimi ve onlara bağlı olarak ortaya çıkacak (sınıfsal) çatışmalar içinde toplumsal dönüşümü ifade etmek, yansıtmak ister" (Kahraman, 2012: 224). Çünkü Orhan Kemal'e göre edebiyat dünyayı değiştirmenin araçlarından biridir (Ümit, 2012: 28).

Genellikle metnin kahramanlarının psikolojik durumları ve onların ruhî büyüme süreçlerine göre şekillenen edebî ürünlerin bilinmeyen ve görünmeyen kısımlarını hem anlamak hem de yorumlamak için çeşitli inceleme yöntemleri mevcuttur. Bu yöntemlerden bir de okura ve araştırmacıya çeşitli bakış açıları sunan sembol dili ve arketipsel sembolizmdir. Sanatkârların büyük bir kısmı düşüncelerini simge, imge ve birtakım göstergelerle aktarmaktadırlar. Orhan Kemal'in de kendisini ve düşüncelerini net ifadelerle anlatmak yerine simge ve imge gibi unsurlar yoluyla yansıttığını belirtmek mümkündür. Makalemizde temel aldığımız sembol dili ve Orhan Kemal'in İki Buçuk adlı hikâyesindeki sembolik yapının işlevini ise metnin anlaşılmasında psikolojik bir çözülme yöntemi olarak kabul etmek mümkündür. Çalışmamıza sembol dili ve özellikle de insanın düşünce, duygu ve davranış kalıplarını şekillendiren psikolojik çözümleme yöntemlerinden biri olan arketipsel sembolizm yön verecektir. Çünkü metinde anlatılmak istenenler bazı sembollerle ortaya konur. Bu sebeple incelediğimiz öykünün temelinde sembollerin, kavramların ve imgelerin kahramanlar vasıtasıyla işlevsel bir şekilde okura aktarıldığını görmekteyiz.

Orhan Kemal'in İki Buçuk adlı hikâyesinde kahramanın ve kendisinin bilinç altının anlam derinliklerindeki saklı anlam şifrelerini hikâye diline sembolik anlatımla yansıtmış olduğu görülmektedir. Özellikle de bireyleşim sürecinde kahramanın simgesel bir yolculuğa çıması ise onun kendini gerçekleştirmesini ve değerler dünyasını şekillendirmesini sağlar. Bu sebeple çalışmada Orhan Kemal'in 1968 yllında yayımlanan ve 1969 yılında Türk Dil Kurumu Öykü Ödülü’nü ve Sait Faik hikâye armağanını kazanan Önce Ekmek adlı hikâye kitabında yer alan İki Buçuk adlı hikâye sembol dili açısından incelenecektir.

\begin{abstract}
“Önce Ekmek; bu söz kullanıldığı yere ve zamana göre, kimi zaman bir slogan, kimi zaman bir dram, kimi zaman bir öfkedir. Ancak bu söz nerede söylenirse söylensin, kanaatimce, kaygıyı ifade ediyor. Nitekim, ‘önce ekmek' sözü, para akışının yön verdiği çağımızda, dünya nüfusunun çoğunluğunun temel kaygısını ifade ediyor. Toplumcu gerçekçi Türk edebiyatının usta ismi Orhan Kemal'in de temel kaygısı 'önce ekmek' sözü ile karşlaștıklarını hatırlayacaklardır. 'Önce ekmek' diyerek hayallerini bırakan nice kahramanı vardır hayatımızın. Orhan Kemal'in kahramanları da onlardır. Yine de umutludur Orhan Kemal” (Vesek, 2008).
\end{abstract}

Yazarın tıpkı İki Buçuk adlı hikâyesinde olduğu gibi şehir hayatını, şehirde yaşama ve şehre tutunma uğraşını çoğu kez de kavgasını anlatan öykülerinde sıradan insanın hayata tutunma çabasını görmek mümkündür. "Kemal, yazınında da sınıflar arasında taraf tutmuş, ezilen, geçim sıkıntısı çeken insanları savunan hikâye ve romanlar yazmıştır" (Şahiner, 2011: 96). Özellikle de "Müşterek istekleri olan insanlık, günün birinde ekmek için hayallerini terk etmeyecek ve daha da güzel bir dünya kuracaklardır" (Vesek, 2008). 
İki Buçuk adlı hikâyede kavramlar ve kişiler arketiplerle ilişkilendirilerek metindeki sembol diline özgü unsurlar anlamlandırılmaya çalışlacaktır. Böylelikle modern hayatın çıkmazında varlık mücadelesi veren hikâyenin başkahramanının yaşadığı ruhsal değişimlerin açıklanması mümkün hâle gelecektir. $\mathrm{Bu}$ anlamlandırılma çabası yazarın ve bireyin iç dünyasına yolculuk yapmaya ve dahası toplumsal yapının incelenmesine fayda sağlayacaktır. Öyküde genel olarak değinilecek temel kavramlar ise kompleksler, bilinç, bilinç altı ve arketiplerdir. Bu hususların öyküdeki görüntülerine, yansımalarına geçmeden önce öykü hakkında kısaca bilgi vermek faydalı olacaktır.

Modernleşmenin ardından kentlere yapılan göçler, makineleşmek gibi toplumsal ve ekonomik hayattaki değişimlerin anlatıldığı İki Buçuk'ta çağına tanıklık eden yazarın gözlemleriyle emekçi kesime yer verilmektedir. "Orhan Kemal, Türk toplumunun dönemsel yansımalarını insan gerçeği ile evrensel düzeyde yeniden kurar. O, Türk edebiyatının 'aydınlık gerçekçilik'ini savunan bir 'aydın’ıdır” (Eliuz, 2012: 166). İki Buçuk'ta da adeta dünyaya, insanlara kırgınlıkları sebebiyle içine kapanmış, sokaklardan çekinen, caddelerde yürürken tedirgin olan, küskünlükleri ve ışıklı, aydınlık taraflarıyla emekçi yoksulların, para kazanmak için çabalayan insanların, yoksul kesimin sorunlarını, psikolojisini yansıtma hususunda oldukça başarılı bir öyküdür (Harmancı, 2014: 425). Özellikle de yazarın toplum düzeniyle, yanlış kentleşmeyle, yozlaşma ve yabancılaşmayla ilgili düşüncelerini aktardığı hikâyede tüm bu tematik hususları sembol dilinin imkânlarından da faydalanarak tespit etmek mümkündür. "İstanbul'un, büyük kentin varoluşlarına, yiten göçen eski semtlere, umarsız ama özlemli yaşamalara, sınıf atlama girişimlerinin çaresiz sonuçlarına geniş bir yelpaze açan Orhan Kemal, çarpık kentleşmenin ilk işaretçisi (Belki de hâlâ tek işaretçisi)"dir. (İleri, 2012: 37).

Toplumsal ve bireysel konulara duyarlı bir yazar olan Orhan Kemal, dönemin hem siyasal hem de toplumsal travmalarının etkisini benliğinde hissederek zaman içerisinde yaşanan tüm değişimleri gündelik pratiklere yansitır. Özellikle de ekmek kavgasından yenik çıkan ve bunu bir türlü çözüme kavuşturamadığı görülen hikâye kahramanı, bir şekilde toplumsal bilinçlenmenin ardından insanların yaşadıkları değişimleri metinde anlatır. Öyle ki "Yaşamı olduğu gibi canlı, hareketli, fotoğrafik bir şekilde aktaran” (Eliuz: 2012, 154) Orhan Kemal hayatın içinde görülen toplumsal olguları hikâyede otobüsteki başkişinin yaşam pratiklerindeki çatışma durumuyla anlatmaya çalışmıştır. Yazarın kahramanlarının pek çoğunda olduğu gibi İki Buçuk adlı hikâyenin başkişisinin de benzer bir kaderi yaşadığını ifade etmek mümkündür. Çünkü onun küçük adamları "bozulma ve çürümenin kendini yok edişi karşısında" çaresiz kalırlar (Eliuz, 2012: 164).

Trajik bir kahramanın ruh hâlini ve davranışlarını anlatan bir öykü olan İki Buçuk hem konusunun güncelliği hem de işleyiş tarzı açısından oldukça başarılıdır. Orhan Kemal'de kendisiyle yapılan bir röportajda hayatın içinden konular seçmek hususundaki hassasiyetini şöyle ifade eder. "Evet, sosyalist çizgide bir eylemim yok, ama yapitlarımda sosyal sınıflar arasındaki durumun ne olduğunu gösteriyorum. Ne dediğini bilen bir yazar için, sınıflar dışında bir edebiyat yoktur zaten. Bir toplumda yaşıyorsak, bu topluma bağımlı olmamak olanaksızdır" (Bezirci, 1984: 49).

Özellikle de toplumdaki emekçi insanların duygu ve düşüncelerine yer vermekten haz duyan yazar, $\dot{I} k i$ Buçuk'un hikâye başkişisine bindiği otobüsteki şoförden bir türlü para üstünü istetemez. Şoförün para üstünü neden vermediğini kendince düşünen başkişi şoförün onun yol ücretini ödediğini bile unuttuğunu aklına getirir. Hatta yolcuların da onunla ilgili olumsuz düşüncelere kapıldığına kanaat getirerek korkar. Bunun üzerine zihninde birçok olumsuz düşünceyle otobüs yolculuğuna devam eder. Hatta modern hayatın sorunları içinde temiz kalabilmiş, dürüst insanın bir örneği olarak otobüsten inerken yol ücretini tekrar ödemek ister. Çünkü "Yoksullar, Orhan Kemal’in bütün düz yazılarında hep 
mağrur, ümit var ve güçlü ahlaki değerler sistemiyle birlikte betimlenir” (Gültekin, 2012: 62). Tam o sırada şoförün ondan para aldığını unutmadığını fark eder. Çünkü şoför inmeden para üstünü verir ve hikâyenin başkişisi düşüncelerinden dolayı utanır. Fiziksel özellikleri belirtilmeyen hikâye başkişisinin duygu ve düşünceleri ise bu şekilde okuyucuyla paylaşlır. Öte yandan metinde başkişi genel anlamda çekingen, etrafındakilerin düşüncelerine fazlasıyla önem veren, kuşkucu, güvensiz, hakkını aramaya bile çekinen, ötekileştirildiğini düşünen biri olarak yansıtılmıştır. Bu bağlamda şunu belirtmekte fayda var ki "Orhan Kemal'in öykülerinde bir direnç havası vardır. İçten içe bir başkaldırı noktası. O neyi anlatırsa anlatsın direnenler örnek olur onun okurlarına. Çünkü o insanların bozduğu düzeni ancak insanların düzeltebileceğine inanırdı" (Sezer, 2012: 149-150).

Çalışmada incelediğimiz bu öykünün tam olarak anlaşlabilmesi, kahramanların iç dünyalarının derinliklerine -bilinç altlarına ve bilinç dışlarına- eğilmekle mümkün hâle gelecektir. Bunun için ise kişilerin düşünceleri aracılığıyla okuyucuya aktarılan kavram, imge ve semboller tespit edilip yorumlanmalıdır. Özellikle de belirli duyguların ortaya çıkmasında ve yorumlanmasında komplekslerin büyük etkisinin olduğu bir gerçektir. İnsan ruhunu olumsuz yönde etkileyecek, onu ortaya çıaracak korkular ve baskılar bu komplekslere örnektir. Benzer bir şekilde kahramanın ruhsal büyüme sürecinde arketiplerin yansımaları, kişilerin kendi benliklerine ulaşma çabaları ve kompleksleri anlatılmaktadır. Öyleyse zamansal ifadeler, mekânlar, sayılar, renkler, isimler, tabiat olayları, rüyalar, geometrik şekiller ve hayvanlar metinlerde sembol dilinin bir ifade vasıtası olarak kullanılabilir. Çalışmaya konu olan İki Buçuk adlı hikâyede ise sembol dilinin ifade vasıtası olarak sayıların, renklerin ve mekânın böylesi bir işleve sahip olduğu görülmektedir.

\section{Arketipsel Semboller}

Orhan Kemal edebî metinlerinde kendi sıkıntı ve tecrübelerinin yanı sıra Türk insanının acılarını, özlemlerini genellikle sembol dilinin imkânlarından da faydalanarak çok süslü olmayan sıfatlarla dile getirir (Yaylağan, 2015: 3); (Kantarcı, 2012: 457). İki Buçuk adlı hikâyede de başkişinin yaşadıkları ve ruhsal değişimi bilinç dışına ait unsurları temsil eden arketipsel sembollerle anlatılmaktadır. "Edebî metinlerin içerisinde rüya, öte âlem, hayal ve sembol gibi farklı görünüşlerle ortaya çıkan arketipler, kişisel ve kolektif bilinç dışındaki duyguların dışa vurumudur" (Yılmaz, 2011: 46). Edebî metinlerde duyguların dışa vurumu şeklinde bir görevi olan arketipsel sembollerin İki Buçuk adlı hikâyenin de kurgusunda oldukça işlevsel bir konuma sahip olduğunu belirtmekte fayda var. Hikâye "İşte gene hiç sevmediği bir duruma düşmüştü!” (Kemal, 2017: 92) cümlesiyle başlar. Bu cümleden de anlaşllacağı üzere başkişi daha önceden de benzer sıkıntılı bir ruh hâline bürünmüştür. Hayata tutunmada zorluk yaşayan başkişi için hayatın içindeki karmaşıklık belki de çıkmış olduğu yolculukta onun için en büyük engeldir. Hikâyede de metnin başkişisine sıra her geldiğinde bazen cümlelerin tamamlanmaması kahramanın parçalanmışlığının, yarım kalmışlı̆̆ının ve ötekileştirildiğinin bir göstergesi olarak kabul edilebilir. "Solunda iki kişi. En sağındaydı. Bozuk paraların en küçüğü iki buçukluk. Öteki müşteriler verince o da onlara uymuş, uzatmıştı iki buçukluğu. Şoför almış, ötekilerin iki buçuk, beşliklerinin üzerini vermiş, onunkini...” (Kemal, 2017: 92-93). Bu gibi tamamlanmamış cümleler aynı zamanda kahramanın toplumda yaşadığı güvensizlik duygusunu da yansıtmaktadır. "Şoför Efendi, iki buçuğun üstünü unuttunuz! dese, şoför belki de, 'Ne biliyorsun unuttuğumu?' diye bozabilirdi. Bozmasa bile, dolmuş yolcuları şöyle bir bakarlar, içlerinden, 'Amma da para canlısı ha! Gibilerden geçirebilirlerdi”" (Kemal, 2017: 93). Simgesel anlamda bireyleşim macerasında değişim mekânı olan otobüste kahramanın güçsüzlüğü ve çekingenliği ise fonksiyonel anlamda ana rahmine denk gelen 'balinanın karnı' olarak değerlendirilebilir (Campbell, 2000: 107). Özellikle de kahramanı iç konuşmalarında sembolik bir anlam taşıyan 'iki buçuk' ibaresinin sık sık tekrarlanması olayın sürekliliğini ve başkişinin 
toplum içindeki silikliğini semboller seviyesindeki göstergelerle onun bilinç dışındaki duygularının yansıması olarak anlamlandırılabilir. Bu açıdan kahraman, ruhsal büyüme sürecinde onu yolundan uzaklaştıran insan, toplum ve medeniyet tarafından hoş karşılanmayan çoğunlukla bilinç dışına attığı kaçınılmaz bir olgu olan gölge arketipiyle yüzleşir.

“İç çekti. Bu hiç de istenecek șey değil. Eli yüzü kan içinde, üstü başı toz toprak, karakola gitmek, şoförden davacı olmak... Üstelik, sağındaki müşterilerle şoförün yanındakiler de herhalde şoförden yana olurlardı. O zaman şoför, 'Bana hakaret etti Komiser Bey!' der, hakaretin şeklini anlatır, müşteriler de onu desteklerdi, hem iki buçukluğun üstü kalırdı, hem de şoföre hakaretten kovuşturma başlayabilir, astarı yüzünden pahalıya gelirdi” (Kemal, 2017: 94).

Bu örnekte de görüldüğü gibi roman ve hikâyelerindeki sosyal gerçekçi tavırla toplumsal hayatın içindeki sancılı değişimi eserlerinde yansıtan "Orhan Kemal'in Türkiye'si ise henüz yaşadığı devrimin siyasi sosyal ağrılarını dindirmiş ama yavaş yavaş da kapitalist iktisadi anlayışın acılı bir şekilde baş gösterdiği Türkiye'dir” (Narlı, 2003: 66). Ayrıca Orhan Kemal’in eserlerinde “1940'tan sonraki romancı kuşağının "idealist gerçekçi” tutumu sosyalizmin uluslararası siyasetiyle ilişkilendirilebilir. (Narlı, 2003: 65).

Analitik psikolojinin verilerinden de faydalanılan arketipsel sembolizmde kahramanın yolculuğu itibarî dünyanın sınırları içinde okuyucuya sunulur. Söz gelişi hikâye kahramanı, bir kavga çıması hâlinde herkesin şoförün tarafını tutacağını düşünmektedir. Bu ruh hâli ise kendiyle sınırlı olan kişinin kendi dışına çıkmaya karar verdiği ilk anda bile anima ve animusuyla karşılaşmasıyla açıklanabilir (Jung, 2009: 177-197). Kahramanın otobüsteki güvensizlik duygusu -toplum tarafından ötekileştirilmiş ferdin ruh hâliyle- bu şekilde somutlaştırılır. Bu semboller kahramanın hikâyenin başında bireyleşme sürecine girmesinde ve bu yola girerken karar aşamasında bulunmasında oldukça fonksiyoneldir. İlla ki yolculuk olumlu ya da olumsuz sonuçlanabilir. Jung da kahramanların bireyleşim süreçlerinin bazen başarısızlıkla sonuçlanabileceğini şöyle izah eder. "Her ne kadar her şey imajlar biçiminde, yani simgesel olarak yaşanmakta ise de ortada hayali tehlikeler değil bir yaşamın yazgısının bağlı olabileceği gerçek riskler bulunmaktadır. Başlıca tehlike de arketiplerin büyüleyici etkilerine boyun eğme tehlikesidir" (Fordham, 2008: 100).

Arketipsel sembolizmdeki aşama arketipi ise başkişinin otobüsteki gözlemlemeleri ve onları yorumlamalarıyla gerçekleşir. Öte yandan toplumsal hayatın içindeki sancılı değişimi ve insanın karmaşık dünyasını buçuklu simgelerle yansıtmaya çalışan yazar için hikâyedeki diğer kahramanların da kimliğinin açık bir şekilde belirtilmeyişi toplumda hayata tutunamayan pek çok kişinin varlığına bir göndermedir. "Sağındakine baktı: Koca burunlu, sarkık gerdanlının biriydi. Beyden değil de efendiden. Böyleleri ukala olurlar" (Kemal, 2017: 93). Gerçekte hikâyenin kahramanı suskunluğunu anlatı boyunca istikrarlı bir şekilde muhafaza eder. Zira suskunluk genellikle hayata tutunamayan insanlara has bir davranış biçimidir. Parçalanmış benliğin yansıması olan bu davranış modeli tıpkı hikâyenin adı gibi buçuklu, yarım kalmış hayatların edebî metindeki bir örneğidir. Bu gibi davranış biçimleri, sayılarla ve renklerle anlatılmaya çalışlan ruh hâlinin sembolik düzlemde yorumlanmasıyla okuyucuya yol gösterecektir. Öte yandan hikâyede kahramanların yarım kalmışlıkları ve hayata tutunamayışları insanın ruhsal bölünmüşlüğü ve kişilik özellikleriyle sembol dilinin çok katmanlı yapısı aracılığıyla sunulur. Örneğin hikâyede "Sağındaki baktı: Koca burunlu, sarkık gerdanlının biriydi" (Kemal, 2017: 93). Gözü yeniden dikiz aynasındaki şoförün 'iki' yüzüne ilişen başkişinin yanındaki sıradan bir yolcunun sarkık gerdanını fark eder. Daha sonra sağındaki yolcuya bakar ve solundaki yolcunun inmek istediğini fark eder. Tıpkı kahramanın kendi yaşantısında olduğu gibi dolmuşta da sürekli iki arada bir derede kalma ve hayata tutunup ona bağlanamama durumu baş göstermektedir. "Aldı, dolaşan 
ayaklarıyla hızla uzaklaştı. Yüzü alev alev yanıyor, kendi kendinden utanıyordu” (Kemal, 2017: 95). Hikâyenin sonundaki bu cümleden de anlaşılacağı üzere çıktığı yolculukta üstüne gelen zorluklarla mücadele edemediği için etrafındakilerden utanan ve bulunduğu ortamdan kaçmak isteyen kişinin durumunu görürüz.

\section{Sembol Dilinde Sayılar}

İnsanın düşünce mekanizmasıyla doğrudan ilişkili ve sembol dilinin bir parçası olan sayılar, edebî eserlerde dışa vurulamayan duygulara, düşüncelere ışık tutması açısından işlevseldir.

"Varlıkları nicelik yönünden, zaman ve mekân üzerinde konumlandıran sayı sistemleri, farklı kültürlerde çeşitlilik göstermelerine karşılık temelde evrensel geçerliliğe sahip anlamlar taşırlar. Sayıların ortaya çıkışıyla, insanın düşünce mekanizması arasındaki ilişkiden hareketle anlam kazanan sayı sembolizmi, sayıların sadece matematiksel işlemlerde değil, aynı zamanda ruhsal yaşantının alanı olan iç dünyamızın ifade şekli olarak da önem kazandığını gösteriı” (Yılmaz, 2011: $51)$.

İncelemiş olduğumuz bu hikâyede de kişilerin ruh hâlleri sayı sembolizminden faydalanılarak metne yansıtılmıştır. Örneğin metinde kahramanların hayatlarındaki ikilikler, yarım kalmışlıklar ve parçalanmışlıklar buçuk ile sembolize edilir. "Yanındaki bozuk paraların en küçüğü iki buçukluk" (Kemal, 2017: 92). Baş kahramanın kâğıt para kullanmaması ve paralarını avucunda sıkıca tutması kahramanın psikolojisini anlamlandırma sürecinde oldukça önemli bir ipucudur. Onun özel bir madeni para cebi vardır ve burada belki de hayata tutunma çabasındaki küçük insanın gücünü korumaya çalıştığı görülmektedir. En önemlisi ise şoföre verdiği para bir, iki ya da üç lira değil, bilhassa iki buçuk liradır. Yarım kalmış, kendini bir türlü tamamlayamamış, büyük şehirde ekmek kavgası için çalışıp çabalayan kahramanın dışa vuramadığı duygularına sembol dilinin imkânlarıyla ışık tutulmaktadır. "Şoför belki de, yarım sağla arkaya dönerdi" ifadesinde şoförün hareketi bile tam değil yarımdır (Kemal, 2014: 94). Ayrıca bu dönüşte bir 'zorlama' ve buna bağlı bir 'lütuf' da vardır. Çünkü 'iki buçuk' ve 'yarım sağ' ifadelerinde olduğu gibi kahramanın hayatı da her ne yaparsa yapsın tamamlanmamıştır yani eksik, uyumsuz, parçalı ve yarımdır. Bu yarım kalmışlı̆̆ı ve parçalanmışlığı ortadan kaldırmak için ise bütünlüğe ulaşmak gerekmektedir. Para ve sayı sembolleriyle anlatılmaya çalışılan kahramanın yolculuğu esnasındaki bu ruh hâli doğrudan arketipsel sembolizmin erginlenme aşamasıyla ilişkilidir. "Onun için vazgeçmeli, hatta iki buçuğun lafını bile etmeden, yeni elli kuruş vermeliydi şoföre" (Kemal, 2017: 95).

Metinde genel olarak sayı sisteminde yarım kalan şeylerin sürekli tamamlanma ihtiyacı içinde olunduğu da görülmektedir. "Göze yasak mı var? Karşılığını alacağını iki kere iki dört eder gibi biliyordu” (Kemal, 2017: 93). Kahramanın çıktığı bireyleşim sürecindeki yolculuğunu başarılı bir şekilde tamamlama çabasıyla da ilişkilendirebileceğimiz bu ruh hâlini nicelikten niteliğe dönen sayı sembolüyle izah etmek mümkündür. Hayatta kendinden ödün vermeden var olamayacağını düşündüğünü anladığımız kahramanın "Elli kuruşluk yolu ne için üç yüz kuruşa gidecekti?” (Kemal, 2017: 95) şeklindeki sorgulamaları da onun hayatta varoluş süreciyle ve hedefine ulaşma isteğiyle doğrudan ilişkilidir.

Metinde geçen "öteki denen insanın sayısı" (Schimmel, 1998: 58) olan iki sayısı ise bölünme ve uyumsuzluğa işaret etmektedir. Sayıların sembolik anlamlarında bu bölünmeyi doğrudan kahramanın ruh hâliyle ilişkilendirebiliriz. Hikâyenin sonunda kahramanın bireyleşim sürecinin 'yarım' ve 'buçuk' kaldığı, asla tamamlanıp bütünleşemediği görülmektedir. Metinde geçen iki buçuk, elli kuruş, üç yüz kuruş ifadeleri ise rakamsal olarak birbirini tamamlamaktadır. Böylece kahraman her ne kadar 
bireyleşim sürecini tamamlayıp utanarak otobüsten inse de bir tür ruhsal bütünlüğe kavuşmuş görünmektedir.

Neticede hikâyenin hem adı olan hem de metinde sık sık yer verilen 'iki buçuk' kelimesinin kullanımı doğrudan sembolik bir anlam taşımaktadır. Kahramanın kimlik bunalımı adeta sayı sembolizminden yararlanarak iki ve buçuk kelimeleriyle ifade edilmeye çalışılır. Kahramanın yarım kalmışlı̆̆ını yansıtan bu kullanım ifadenin işlevine ve ona yüklenen anlamlara göre metinde sembol dili özelliği göstermektedir. Öyleyse metinde yer alan sayıların hemen hepsinin sembol dili özelliği gösterdiğini söylemek mümkündür.

\section{Sembol Dilinde Mekân}

İnsan psikolojisinin çözümlenmesinde önemli bir rol oynayan mekân hikâye ve romanlarda çeşitli şekillerde sembolize edilmektedir. "Mekân, insanın psikolojik durumuna göre şekillenerek, ruhsal yapısından hareketle boyut kazanır. (...) Temaya ve kişilerin ruhsal dünyalarına dair önemli ipuçlarına işaret eder" (Yllmaz, 2011: 49-50). Bu bağlamda mekân-insan ilişkisinden hareketle metnin çözümlenmesine yardımcı olan her bir unsur ve değişsim kahramanın ruhsal yapısını yansıtma işlevine göre anlam kazanmaktadır.

İnsan merkezli eserler yazan Orhan Kemal İki Buçuk’ta da eleştirel bir üslupla toplumsal gerçekliğe yer vermektedir. "Orhan Kemal öykülerinin geneli, insan-mekân ilişkisi bağlamında değerlendirildiğinde bu ilişkinin sadece yaşanılan çevre düzeyinde olmadığı, simgesel ve imgesel göndermeler yoluyla mekânların, kişilerin yaşam biçimleri, sosyo-kültürel yapıları ve kişilik özellikleri üzerinde belirleyici olduğu görülür" (Kuş, 2014: 334). İnsanın hemen her hâlini yazarken aynı zamanda bozuk toplum yapısına eleştirilerde bulunan Orhan Kemal'in eserlerinin konusu büyük oranda "Toplumsal gerçeklik bütün olumsuz yönleriyle, çürümüşlüğüyle, acımasızlığıyla, çirkinliğiyle ve tabi içinde taşıdı̆̆g 'iyilik' potansiyeliyle" tasvir edilir (Erdoğan, 2014: 45).

İster istemez zamanın ve mekânın ruhu sanat eserine yansır. Özellikle de "Kırsal toplumsal yapıların çözülmesiyle kentlere doğru akan yoksul kitleler, tarımsal üretim tekniklerindeki radikal dönüşüm sonucu, daha önceki evrelerinden hiçbirinde rastlanmayan servet birikimlerinin yeni örüntüsü, araçları ve sonuçları olan yeni insan ilişkileri..." (Gültekin, 2014: 83) Orhan Kemal'in eserlerinde hayat bulur. İki Buçuk adlı hikâye de insanların çok sık bir araya geldiği otobüs durağında başlar. Durağın simgesel düzlemdeki işlevi oldukça kalabalık bir ortam olması ve kahramanın bu kalabalıktaki silikliğini, bireyleşim macerasının burada başladığını anlatmak içindir. Kahramanın gitmek istediği Cağaloğlu da kalabalıktır. Metinde kalabalık mekânların seçilmesi tesadüfi değil tam aksine metin içerisinde oldukça işlevseldir. Çünkü metinde mekân daha çok simgesel ifadelerle ortaya konularak sembolik fonksiyon üstlenir. Yani mekân hikâyede geçen olayları ifade etmekte kullanılan simgesel bir değere sahiptir. Mekânın işlevi kişinin kendi sınırlarını aşmasında ve kendini gerçekleştirmesinde simgesel bir anlam ifade eder. Hikâyede kahramanın mekânla olan ilişkisinden hareketle daha çok kişi ve toplum düzeyindeki problemler, adaletsizlik, ötekileştirme, yozlaşma gibi sosyal meselelerin sorunsallaştırıldığını görülmektedir. Hiç şüphesiz ki eserdeki semboller ifade edilmek istenenlerin anlatılmasına çoğu kez katkı sağlar: "Başkişileri, maddi kaygıların şekillendirdiği yaşamları ile küçük adam figürü etrafında sembolik anlatım tarzları ile kurgulandırılır. Kişilere ait psikolojik durumlar, nesnel sembollerin çağrışım değerleri ile ifade edilirken; mekân ve zaman unsurlarının, kişisel alandaki önemi de vurgulanmış olur" (Eliuz, 2018: 165). 
Kahramanın gözünde labirent bir mekâna dönüştüğünü ifade edebileceğimiz ve durakta başlayıp otobüste devam eden ruhsal değişim sürecinde mekân, ruhsal bütünlüğe ulaşmada yolculuğun ilk aşamasıdır. Özellikle de büyük şehirlerde adeta "Evlerine ekmek götürmek derdindeki dertli erkekler, kadınlar, çocuklar maddî dünyanın sert koşulları altında sanki sonuçsuz gibi duran bir 'kavga'nın içindedirler" (Gürkan, 2014: 148). Yazar da Önce Ekmek'teki hemen hemen bütün hikâyelerde özellikle de sanayileşme ve kentleşmenin ardından Türkiye'nin geçirdiği büyük değişimin kötürümleşmesini, yozlaşmasını 'sıradan' simaların hayata tutunma çabalarını işler. Çünkü onun eserlerinde "Yol gösteren, insanları bozuk düzenden nasıl kurtaracağını eylemleriyle veya sözleriyle ortaya koyan 'idealize tip’ler” bulamayız (Narli, 2002: 27).

Kahramanın ruhsal bunalımlarının, iç çatışmalarının ve bireysel var oluş sürecinin işlendiği İki Buçuk'ta insan ruhunun gizli kalmış yönlerini görünür kılan durak, cadde, İstanbul, Cağaloğlu ve otobüs sembol dilinin mekâna yansıyan dışavurumu olarak değer kazanır.

\section{Sembol Dilinde Renkler}

Kahramanın yaşadığı bireyleşim macerasında metinde yer alan renklerin simgesel anlamlar taşıdığını ifade etmek mümkündür. Hikâyede bir tek sarı renge yer verilmiştir. Geçmişten bugüne çeşitli şekillerde sembolleşen renklerden sarı renk olumlu özellikleriyle altının, gücün, mevkinin simgesi olarak ve Türklerde hastalık gibi olumsuz özellikleriyle de karşımıza çıkar (Naskali, 2017: 39-41); (Çoruhlu, 2010: 215-216).

Hikâyenin kahramanı hayatın hemen her aşamasında kendini güvensiz hissettiği için elindeki parayı sıkıca tutmaktadır. Bu bağlamda kahramanın elindeki paranın renginin sarı olması metnin daha iyi anlaşlabilmesi için oldukça önem arz etmektedir. "Pantolonunun bozuk para cebinden iki tane sarı yirmi beşlik çıkarıp elinde tuttu." (Kemal, 2017: 95). Çünkü paralarını kaybetme korkusu yaşayan başkişi için sarı rengin ayrılıkla ve hayata tutunamamakla ilişkili olması onu sımsıkı tutmasına neden olur. Diğer yandan sarı renk ilham verici özelliğinden dolayı zihin karışıklı̆ına da sebep olabilmektedir. Metinde geçen kahramanın çeşitli çatışmalardan ibaret iç konuşmaları da bu ruh hâline örnek gösterilebilir. Hikâyedeki iç konuşmalar ise kahramanın ruh dünyasının sembolik düzlemde bir anlamı olarak karşımıza çıkar ve tematik vurguyu güçlendirir.

\section{Sonuç}

"Orhan Kemal de tüm insanlar için sömürü, yoksulluk ve haksızlıktan uzak, ideal bir dünya özleminin gurbetçisidir” (Akdağ, 2014: 225).

Edebî metinlerin incelenmesinde değişik yöntemler kullanılmaktadır. Bunlardan biri de herkeste görülen benzer psişik durumlar olan arketipsel sembollerin açığa çıkarılmasıdır. Arketipsel sembolizm metin çözümlemesinde kişinin kolektif bilinç dışı donanımını oluşturduğu için metnin anlaşılmasında okura büyük kolaylıklar sağlamaktadır. Günlük dilin sınırlarının genişletilmesiyle farklı ve özgün anlatı yöntemleri ortaya koyan semboller ise sadece edebî metinlerde değil illa ki hayatın hemen her alanında kendine yaşam imkânı bulacaktır. Sembol kullanımı özellikle de roman ve hikâye gibi edebî türleri tek boyutluluktan uzaklaştırarak anlam derinliği ve zenginliği kazandırmaktadır. Özellikle de zengin bir imgeyle yayımlanan edebî metinler için sembollerin dili oldukça önemlidir. Hikâyede kahramanın simgesel olarak yaptığı yolculuk ise başkişinin kendi var oluşu; ayrılış, erginlenme ve dönüş safhalarından oluşur. Bu safhalar ise edebî metinlerde genellikle bilinç dışının arketip ve mitik simgeleriyle ortaya konmuştur (Şahin, 2009: 2101). Kahramanın sembolik anlamda yaptığı yolculuktan 
bireyleşme sürecini tamamlayarak dönmesi ise kendisini sembollerle var eden bilinç dışının anlaşılmasına katkı sağlayacaktır (Karagözlü, 2012: 1416).

Görüldüğü üzere insanın gerçeklerini yansıtmaya çalışan edebî metinlerde kişilerin benliklerini arama maceralarını anlamada ve yorumlamada semboller oldukça önemlidir. İki Buçuk'ta da asıl tema ahlâkın ve erdemin bir adamın davranışlarında somutlaştırılmasıdır. İşte bu amaca hizmet noktasında metindeki sembollerin her birinin ayrı bir fonksiyonu bulunmaktadır. Yarınları inşa sürecinde insanlığa inanan ve onlara çeşitli roller yükleyen Orhan Kemal insan psikolojisini yansıtma hususunda da oldukça başarılıdır. Özellikle de modernleşmeyle yaşanan değişimin ve dönüşümün, toplumsal sınıf farklılıklarının, geleneksel değerlerin aşınması somut bir şekilde yazarın hikâyelerine yansıtılmaktadır. Şehirlerin kültürel yapısındaki karmaşa da sembol diline özgü unsurlarla hikâyeye aktarılmıştır. Neticede tüm bu tespitler yazarın kullandığı semboller ve bunlarla kurulan derinlik, hikâyenin önemini artırmış gibi gözükmektedir. Orhan Kemal'in özellikle de hikâyelerindeki insan sevgisi sınıflar arasındaki mücadele, insanların umutları, adalet arayışı oldukça önemli hususlardır. Yoksulluk, açlık ve işsizlik gibi durumların yol açtığı olayların anlatıldığı metinlerde ise kendini gerçekleştirmenin arayışı içindeki kahramanın trajik yaşamının özetidir adeta her bir ayrıntı. Bir otobüs yolculuğu esnasında yaşanan olayların aktarıldığı "İki Buçuk" başlıklı hikâyede ise semboller insanın karmaşık dünyasını simgeleyen ve bilinç altına açlan bir nesne olarak önemli bir konuma sahiptir.

\section{Kaynakça}

Akdağ, E. (2014). “Orhan Kemal'in Roman ve Öykülerinde Göç ve Gurbet”, Hece (Bereketli Topraklarm Yazarı Orhan Kemal), S. 205, Ocak, ss. 225-234.

Bezirci, A. (1984). Orhan Kemal, İstanbul: Tekin Yayınevi.

Bilgegil, K. (1980). Edebiyat Bilgi ve Teorileri, Belagat I, İstanbul: Enderun Kitabevi.

Campbell, J. (2000). Kahramanin Sonsuz Yolculuğu, İstanbul: Say Yayınları.

Çobanoğlu, Ş. (2013). “Carl Gustav Jung'un Çağrışım Deneyleri Işığında İlhan Berk’in Şiirlerinde Ev ve Çevresindeki Nesnelerin Yorumu”, Yeni Türk Edebiyatı Araştırmalar, S. 9, ss. 57-72.

Çoruhlu, Y. (2010). Türk Mitolojisinin Ana Hatları, İstanbul: Kabalcı Yayınevi.

Demirel, Ş. (2012). "Sembol, Sembolik Dil ve Bu Bağlamda Mesnevînin İlk 18 Beytindeki Sembolik Unsurlar", Turkısh Studies, ss. 915-947.

Durmuş, M. (2011). "İmge-Sembol Kavramlarını Yorumlama Projesi ve Melih Cevdet Anday Şiirinde İmge”, Turkish Studies, S. 6, ss. 745-762.

Eliuz, Ü. (2009). Orhan Kemal ve Romancılı̆̆ Ankara: MEB.

Eliuz, Ü. (2012). “Orhan Kemal’in Romanlarında Dil ve Üslup”, Orhan Kemal, Ankara: Kültür ve Turizm Bakanlığ 1 , ss. 151-167.

Erdoğan, A. (2014). “'Aydınlık Gerçekliğin’ Rotası”, Hece (Bereketli Toprakların Yazarı Orhan Kemal), S. 205, Ocak, ss. 43-48.

Ergin, M. (1995). Dede Korkut Kitabı, İstanbul: Boğaziçi Yayınları.

Erol, M. (2014). “Orhan Kemal'in Dünyası: Baba ve Devlet, Ev ve Vatan”, Hece (Bereketli Topraklarm Yazarı Orhan Kemal), S. 205, Ocak, ss. 104-113.

Fordham, F. (2008). Jung Psikolojisinin Ana Hatları, (çev. Aslan Yalçıner), İstanbul: Say

Gültekin, M. N. (2012). “Bir Anlatı Ustasının Penceresinden Toplum, İnsan, Dönem”, Orhan Kemal, Ankara: Kültür ve Turizm Bakanlığı, ss. 39-65.

Gültekin, M. N. (2014). "Köyler, Kentler ya da Bütün Hayat Modernleşirken", Hece (Bereketli Topraklarm Yazarı Orhan Kemal), S. 205, Ocak, ss. 81-95. 
Gürkan, A. (2014). "Marksist Dünya Görüşü Ekseninde Orhan Kemal’in Anlatılarına Genel Bir Bakış", Hece (Bereketli Topraklarm Yazarl Orhan Kemal), S. 205, Ocak, ss. 137-157.

Harmancı, A. (2014). “Orhan Kemal'in Günlükleri”, Hece (Bereketli Topraklarn Yazarl Orhan Kemal), S. 205, Ocak, ss. 422-428.

İleri, S. (2012). "Yazmaya Orhan Kemal Olacaktı", Orhan Kemal, Ankara: Kültür ve Turizm Bakanlığı, ss. 36-38.

Jung, C. G. (2009). İnsan ve Sembolleri, (Çev. Ali Nahit Babaoğlu), İstanbul: Okyanus Yayınları.

Kahraman, H. B. (2012). “Orhan Kemal: Durum ve Karakter Romancısı”, Orhan Kemal, Ankara: Kültür ve Turizm Bakanlığ

Kantarcı, A. (2012). "Orhan Kemal'in Hikâyeciliğinde Toplumcu Gerçekçiliğin İzleri”, Orhan Kemal, Ankara: Kültür ve Turizm Bakanlığı, ss. 449-462.

Karacanlar, K. (1984). Orhan Kemal, 1974, s.106, Aktaran: Asım Bezirci, Orhan Kemal, İstanbul: Tekin Yayınevi.

Karagözlü, V. (2012). "Arketipsel Sembolizm Bağlamında Mihr ü Vefâ Mesnevisinin İncelenmesi”, Turkısh Studies, S. 7/1, 1405-1421.

Kemal, O. (2017). Orhan Kemal-Önce Ekmek, İstanbul: Everest Yayınları.

Kuş, D. (2014). Orhan Kemal'in Öykülerinde 'Suç ve Çocuk”', Hece (Bereketli Topraklarnn Yazarı Orhan Kemal), S. 205, Ocak, ss. 333-337.

Narlı, M. (2002). Orhan Kemal’in Romanlar Üzerine Bir İnceleme, Ankara: Kültür ve Turizm Bakanlığı.

Narlı, M. (2003). “Gorki’nin ve Orhan Kemal'in Küçük Adamları”, İlmî Araştırmalar, S. 16, İstanbul, ss. 65-76.

Naskali, E. G. (2017). Renk Kitabl, İstanbul: Kitabevi.

Orhan, K. (1974). Türkiye Defteri Orhan Kemal Özel Sayısı, S. 10, Ağustos, İstanbul.

Özünel, E. Ö. (2015). "Baharı Getiren Kahraman: Bamsı Beyrek”, Millî Folklor, S. 107, ss. 34-48.

Schımmel, A. (2000). Sayıların Gizemi, İstanbul: Kabalcı Yayınları.

Sezer, Ş. (2012). "Orhan Kemal ile İkbal'de Bir Sabahiye”, Orhan Kemal, Ankara: Kültür ve Turizm Bakanlığı, ss. 146-150.

Şahiner, S. (2011). "6o'lar Türk Sineması'nda Orhan Kemal Senaryolarında 'Zenginlik' Teması", Marmara Üniversitesi Sosyal Bilimler Enstitüsü Radyo Televizyon ve Sinema Anabilim Dah Sinema Bilim dalı, (Yayımlanmamış Yüksek Lisans Tezi), İstanbul.

Türkçe Sözlük, (1986). Ankara: TDK.

Ümit, A. (2012). "Edebiyatımızın Ağır İşçisi Orhan Kemal”, Orhan Kemal, Ankara: Kültür ve Turizm Bakanlığı, ss. 23-28.

Vesek, M. (2008). Önce Ekmek, Cumhuriyet Kitap, http://www.orhankemal.org/links/405.htm (ET: 09.05.2018)

Yaylağan, N., (2015). "Orhan Kemal'in Roman ve Hikâyelerinin Dili ve Türkçe Bakımından Değerlendirilmesi”, Dokuz Eylül Üniversitesi Eğitim Bilimleri Enstitüsü Ortaöğretim Sosyal Alanlar Eğitimi Ana Bilim Dah, (Türk Dili ve Edebiyatı Öğretmenliği Doktora Programı Yayımlanmamış Doktora Tezi), İzmir.

Yıldırım, N. (2009). "Sembolik Bir Dil Hazinesi: Halk Anlatıları", Turkish Studies, S. 4/8, ss. 23832403. 